\title{
Fabrication and characterization of tilted R-plane sapphire wafer for nonpo- lar a-plane GaN
}

\author{
Jin Ki Kang and Young Jin Kim ${ }^{\dagger}$ \\ Department of Materials Science \& Engineering, Kyonggi University, Suwon 443-760, Korea
}

(Received July 8, 2011)

(Revised July 15, 2011)

(Accepted July 22, 2011)

\begin{abstract}
Tilt angle of r-plane wafer is a one of the important factors related with the quality of the GaN epi, so the fine control of the tilt angle is important for the growing of high quality non-polar a-GaN epi. We prepared the R-plane sapphire wafers with slight tilt angles for nonpolar a-plane GaN. The target tilt angles of $\alpha$ and $\beta$ were $0,-0.1,-0.15$, $-0.2,-0.4,-0.6^{\circ}$ and $-0.1,0,0.1^{\circ}$, respectively. The tilt angles of sliced R-plane sapphire wafers were measured by $\mathrm{x}$-ray and the statistical evaluation of reliability of tilt angles of wafers were performed. The tolerance of the tilt angle was $\pm 0.03^{\circ}$. R-plane sapphire wafers have relatively large distributions of BOW and TTV data than c-plane sapphire wafers due to the large anisotropy of R-plane. As the tilt angle $\alpha$ was increased from -0.1 to $-0.6^{\circ}$, the step widths and heights were decreased from $156 \mathrm{~nm}$ to $26 \mathrm{~nm}$ and $0.4 \mathrm{~nm}$ to $0.2 \mathrm{~nm}$, respectively. The growth and qualities of GaN epi seems to be largely affected by the change of step structure of R-plane sapphire wafers with tilt angle.
\end{abstract}

Key words Sapphire wafer, Nonpolar GaN, Tilled angle, Slicing, DMP, CMP

\section{경사각을 갖는 비극성 a-GaN용 R-면 사파이어 기판의 제조 및 특성}

\section{강진기, 김영진}

경기대학교 재료공학과, 수원, 442-760

(2011년 7월 8일 접수)

(2011년 7월 15일 심사완료)

(2011년 7월 22일 게재확정)

초 록 비극성 a-GaN의 성장 시 기판의 경사각은 $\mathrm{GaN}$ epi의 품질을 결정하는 중요한 변수로서 양질의 a-GaN 성장을 위해서는 $\mathrm{R}$-면 기판의 경사각이 정밀하게 제어된 기판이 요구된다. 본 연구에서는 $\mathrm{R}$-면 기판의 경사각 $\alpha$ 와 $\beta$ 의 목표값이 각각 $0,-0.1,-0.15,-0.2,-0.4,-0.6^{\circ}$ 와 $-0.1,0,0.1^{\circ}$ 인 절단기판을 제조하였다. 절단기판의 경사각을 $\mathrm{x}-\mathrm{ray}$ 를 이용하여 측정 하고 통계적인 분석을 통해 기판의 경사각 제어공정에 대한 신뢰성을 평가하였으며, R-면 기판의 경사각의 공차는 $\pm 0.03^{\circ}$ 의 값을 가졌다. R-면 기판은 상대적으로 큰 이방성에 의해 c-면 기판에 비해 휨(BOW)과 두께편차(TTV)가 상대적으로 큰 분포를 갖는 것으로 나타났다. $\mathrm{AFM}$ 을 이용하여 기판 표면을 관찰한 결과, 측정된 $\mathrm{R}$-면기판의 step 높이는 $0.2 \sim 0.4 \mathrm{~nm}$ 로 거 의 일정한 값을 가졌으며 step 너비는 경사각 $\alpha$ 가 증가함에 따라 $156 \mathrm{~nm}$ 에서 $26 \mathrm{~nm}$ 로 감소하였으며 이와같은 R-면 기판의 step 구조의 변화는 epi 성장에 큰 영향을 미치는 것으로 판단된다.

\section{1. 서 론}

현재 상용화되어 있는 $\mathrm{GaN}$ 계 $\mathrm{LED}$ 용 기판재료로는 c-면 사파이어 기판이 가장 널리 이용되고 있으나, c-면 $\mathrm{GaN}$ 발광층은 자발분극(spontaneous polarization)과 압 전분극에 의해 내부양자효율의 저하되어 $[1,2]$ 고휘도

\footnotetext{
Corresponding author

Tel: +82-31-249-9766

Fax: +82-31-249-9775

E-mail: yjkim@kyonggi.ac.kr
}

LED 응용에 있어서 제한이 되고 있으며 이를 근본적으 로 해결하기 위해서 비극성(non-polar) GaN LED를 성 장하기 위한 시도가 이루어져 왔다[3-10].

Wurtzite 결정구조를 갖는 $\mathrm{GaN}$ 계 화합물은 c-면 사파 이어를 사용하여 (0001) 결정면 위에 성장되는데 c-축으 로 우선 배향된 Wurtzite 결정의 non-centrosymmetric(c 축 방향을 따라 위쪽은 $\mathrm{Ga}$ 원자, 아래쪽은 $\mathrm{N}$ 원자로 이 루어진 형태) 특성 때문에 자발분극을 가지게 된다. 또 한 이종접합 구조를 형성할 때 $\mathrm{GaN}$ 과 사파이어 간의 큰 격자상수의 차이, 같은 c-축 배향성을 가진다는 특성 
으로 인한 응력이 발생하여 압전분극도 함께 생기며, 질 화물의 압전계수는 매우 큰 값을 가지므로 작은 변형에 도 매우 큰 분극을 초래할 수 있다 $[1,10]$. 분극으로 유 발된 정전기장은 양자우물 구조의 에너지 밴드 구조를 변화시켜 전자와 정공의 분포를 왜곡시키고, 빛을 만드 는 전자와 정공들의 적절한 재결합을 방해한다. 이러한 현상은 소자의 전기적 - 광학적 특성에 커다란 영향을 미 치는데, 전자와 홀의 공간적 분리로 인한 내부양자 효율 저하의 원인이 되고, 문턱 전압을 높이는 등의 악영향을 미치게 되며, 이것이 기존의 극성 $\mathrm{c}$-면 $\mathrm{GaN}$ 의 발광효 율의 한계이다 $[1,10]$.

비극성 기판을 사용하여 성장된 $\mathrm{a}$-면 또는 $\mathrm{m}$-면의 $\mathrm{GaN}$ 에피층은 c-축이 표면과 평행하게 성장이 되어서 극 성을 띄지 않게 됨으로써 분극현상에 의한 내부양자효율 을 획기적으로 증가시킬 수 있다. 그러나, 비극성 $\mathrm{GaN}$ 은 성장속도의 이방성이 커서 LED 소자에 응용 가능한 양 질의 에피층을 성장시키기 어렵다는 문제점을 갖고 있으 며 이를 해결하기 위한 많은 시도가 이루어져 왔다. 그 중 하나로 경사각을 가지는 $\mathrm{R}$-면 사파이어를 기판으로 이용하여 비극성 $\mathrm{GaN}$ 의 결정성과 표면 거칠기를 항상시 키기 위한 연구들이 진행되어 왔다[2-10]. 현재까지의 연 구결과 기판의 경사각이 $\mathrm{GaN}$ 에피 성장에 큰 영향을 미 치며 이는 기존 사파이어 $\mathrm{c}$-면 기판의 경우 특정 경사각 을 갖는 것과 유사한 경향으로 생각된다[1-4]. 그러나, 기 존의 연구에서 경사각의 범위와 오차범위가 커서 경사각 이 미치는 영향을 명확히 밝히는 데는 한계가 있으며 사 파이어 기판의 경사각과 표면의 pit 형성에 관한 상관관 계와 메커니즘에 대한 체계적인 연구는 상대적으로 많이 진행되지 않았는데 이는 에피 성장에 필요한 $\mathrm{R}$-면 기판 의 수급제한에 기인하는 부분이 있다. 양질의 비극성 $\mathrm{GaN}$ 에피 성장을 위해서는 양질의 기판이 반드시 요구 되지만 LED용 R-면 기판은 현재 연구 개발 단계에 있으 며, 고품질의 R-면 기판을 구하기 어려우며, 가공 특성 및 품질기준에 대한 연구 또한 거의 보고된 바 없다[11].

본 연구에서는 기존의 연구결과 양질의 a-plane $\mathrm{GaN}$ epi 성장에 적합한 것으로 보고된 (-)tive $\alpha$ 의 경사각을 갖는 R-면 기판을 제작하여 기판의 경사각 분포 및 기 판의 주요 특성인 휨(BOW), 두께편차(TTV) 등을 측정 하고 통계적인 평가와 기존 $\mathrm{c}$-면 기판과의 비교분석을 통해 R-면 기판의 가공 특성에 대한 연구를 수행하였으 며, 기판의 경사각에 따른 표면형상의 변화를 $\mathrm{AFM}$ 을 이용하여 분석하였다.

\section{2. 실험방법}

사파이어 결정의 결정구조와 사파이어를 LED 기판재

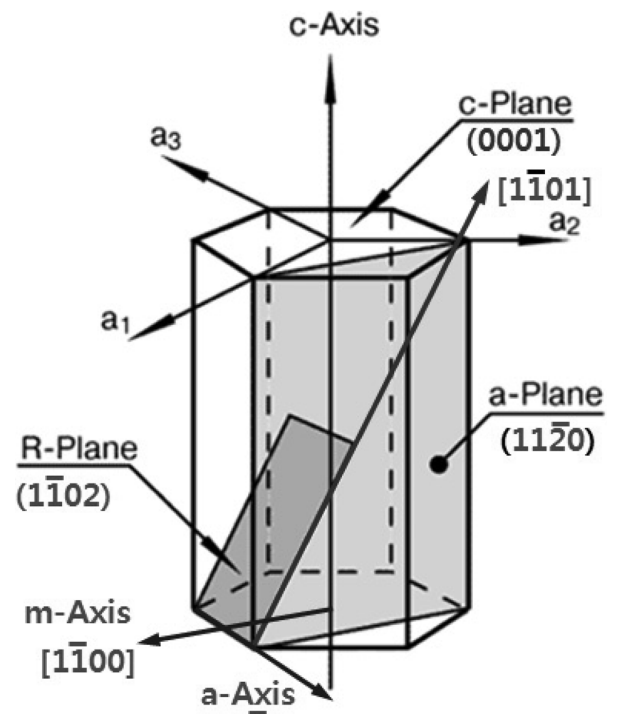

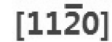

Fig. 1. Indices of some directions and planes of sapphire crystal.

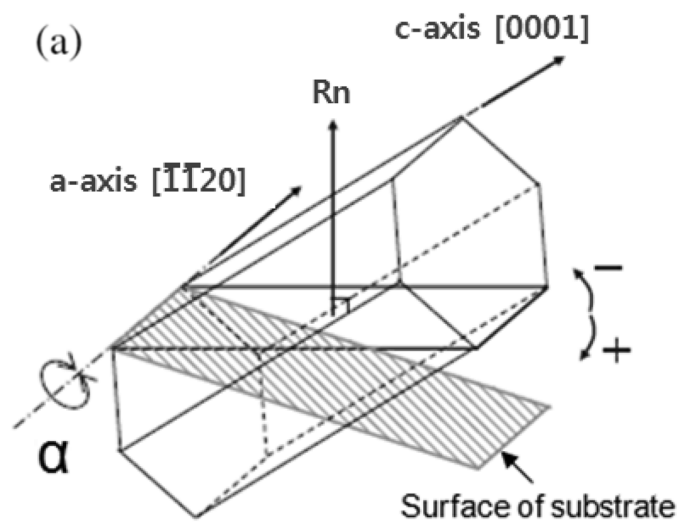

(b)

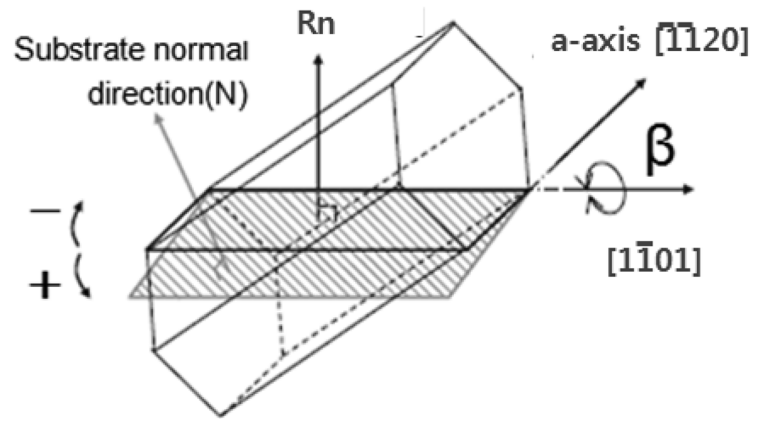

Fig. 2. Definition of tilt angle $\alpha$ and $\beta$.

료로 응용하는 경우에 중요한 결정면과 결정방향을 Fig. 1 에 나타내었다. R-면 기판의 경사각은 Fig. 2 에 표시된 $\alpha$ 와 $\beta$ 로 정의된다. 실제 $\mathrm{R}$-면 기판에 수직한 방향과 (1102) R-면에 수직한 방향이 이루는 각도가 경사각이며, 이 경사각을 정의하기 위하여 $\mathrm{R}$-면 상의 $\mathrm{a}$-축 방향과 [1101] 방향을 회전축으로 회전하였을 때 기판면이 R-면 
Table 1

Tilt angle of R-plane Sapphire wafers

\begin{tabular}{ll}
\hline Tilt angle & Target angle \\
\hline$\alpha\left(^{\circ}\right)$ & $0,-0.1,-0.15,-0.2,-0.4,-0.6$ \\
$\beta\left({ }^{\circ}\right)$ & $-0.1,0,0.1$ \\
\hline
\end{tabular}

과 이루는 각도를 각각 경사각 $\alpha$ 와 $\beta$ 로 정의한다[8]. a축을 회전축으로 $\mathrm{R}$-면을 $\mathrm{c}$-축과의 반대방향으로 회전하 였을 때를 $(+) \alpha$, c-축 방향으로 회전하였을 때를 $(-) \alpha$ 로 정의한다. $\beta$ 는 $[1 \overline{101}]$ 방향을 회전축으로 회전하였을 때 $\mathrm{R}$-면과 기판면이 이루는 각도로 정의된다. 앞선 연구에 의하면 R-면 사파이어 기판에 $\mathrm{a}-\mathrm{GaN}$ 을 성장하는 경우에 경사각 $\beta$ 에 의한 영향은 거의 없으며, 주로 경사각 $\alpha$ 에 의한 영향이 큰 것으로 보고되어 있다[8]. R-면 기판이 c-축 방향으로 회전된 경우인 (-)tive $\alpha$ 의 경사각을 가지 는 기판이 양질의 a-GaN 성장에 유리한 것으로 보고되 어 있다. R-면 기판의 경사각이 $\mathrm{a}-\mathrm{GaN}$ 의 에피성장과 품 질에 미치는 영향에 대한 기존의 연구에서 경사각 $\alpha$ 는 $-1.0 \sim 1.0( \pm 0.02),-0.4 \sim 0.4$ 의 범위를 갖는다[2-10].

본 연구에서는 Table 1 에 나타낸 바와 같이 경사각 $\alpha$ 의 목표값을 $0,-0.1,-0.15,-0.2,-0.4,-0.6^{\circ}$ 로 정하였 으며, 경사각 $\beta$ 는 $-0.1,0,0.1^{\circ}$ 로 정하여 기판을 제작하 였다. 경사각을 제어하기 위해서 경사각 $(\alpha, \beta)$ 이 $\pm 0.01^{\circ}$ 공차 이내에 들어가도록 평면 연삭기를 이용하여 잉곳의 양 끝단이 가동된 잉곳을 유리재질의 더미빔(dummy beam)에 에폭시를 이용하여 잉곳을 접착하고 이를 work plate에 고정시킨 후 MWS(Multi wire saw)의 work table에 장착한다. work table은 수평 - 수직 방향으로 회 전이 가능하며 원하는 경사각 $\alpha, \beta$ 값의 제어가 가능하 다. R-면 잉곳을 멀티와이어 쏘를 이용하여 특정 방위각 을 갖도록 절단한 후 100 매 이상의 절단기판에 대해서 경사각을 실측하여 경사각의 제어에 대한 신뢰성을 평가 하였다. 절단기판은 래핑, 열처리, 에지그라인딩, 다이아 몬드 폴리싱, $\mathrm{CMP}$ 공정 등 일반적인 기판가공 공정을 거쳐 가공하였으며, 최종 가공된 R-면 기판은 Nidek사 의 표면형상 분석장치(model FT-17)를 이용하여 BOW, SORI, TTV(Total Thickness Variation) 등을 측정하여 통계프로그램인 "MINITAB"을 이용하여 공정 제어능력 을 평가하였다. AFM(NanoNavi, L-trace II)을 이용하여 경사각에 따른 기판의 표면형상을 관찰하였다.

\section{3. 결과 및 고찰}

\section{1. $\mathrm{R}$-면 기판의 경사각}

절단기판의 방위는 이후 연마공정에서 거의 변화하지
않으나, 절단공정 조건의 제어가 부적절하여 절단기판의 $\mathrm{BOW}$ 와 TTV가 클 경우에는 후속공정인 연마공정에서 연마량이 증가하여 기판의 방위가 바뀔 수 있으므로 경 사각의 제어가 어려워질 수 있다. 따라서 사파이어 기판 의 방위, 즉 경사각을 제어하기 위해서는 절단공정에서 경사각을 정확히 조절해야 함은 물론 절단기판의 $\mathrm{BOW}$ 와 TTV 등의 제어가 이루어져야 한다. R-면 잉곳은 c면 잉곳에 비해서 이방성이 크기 때문에 절단기판의 $\mathrm{BOW}$ 값이 c-축 잉곳에 비해 크다는 특징을 가지며 이 후 연마공정에도 영향을 미치는 것으로 나타났다[12].

Fig. 3과 Fig. 4는 각각 $\alpha=-0.10^{\circ}, \beta=0.00^{\circ}$ 와 $\alpha=$ $-0.15^{\circ}, \beta=0.00^{\circ}$ 의 경사각을 목표값으로 절단된 절단기 판에 대한 MINITAB 분석결과이다. $\alpha=-0.10^{\circ}$ 를 목표 값으로 절단한 웨이퍼 134 매에 대해 측정된 경사각 $\alpha$ 의 평균값은 $-0.11^{\circ}$ 이고 표준편차는 $0.0102^{\circ}$ 이다. 경사각의 가공오차를 $\pm 0.03^{\circ}$ 로 설정하였을 경우 실측된 134 매는

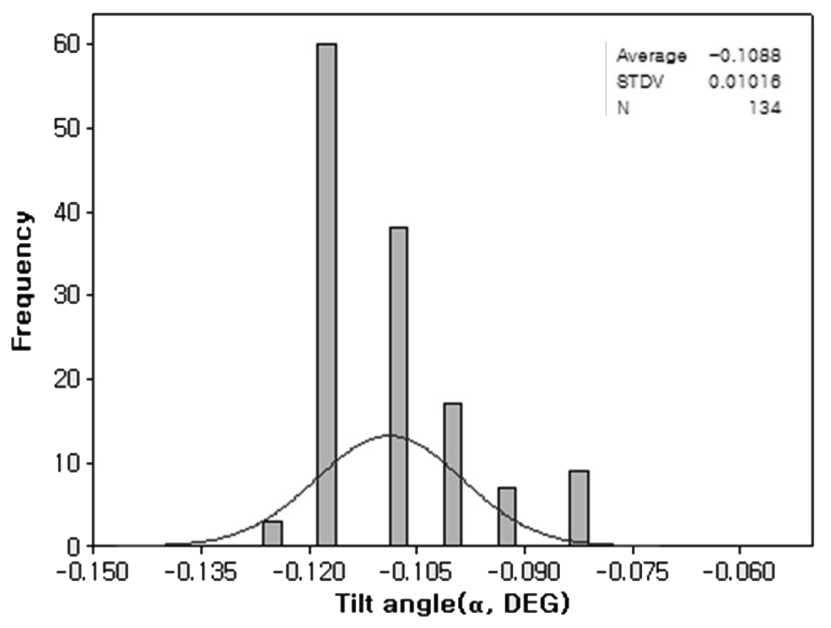

Fig. 3. Distribution of tilt angles of 134 sliced wafers (target $\alpha=-0.1^{\circ}$ ).

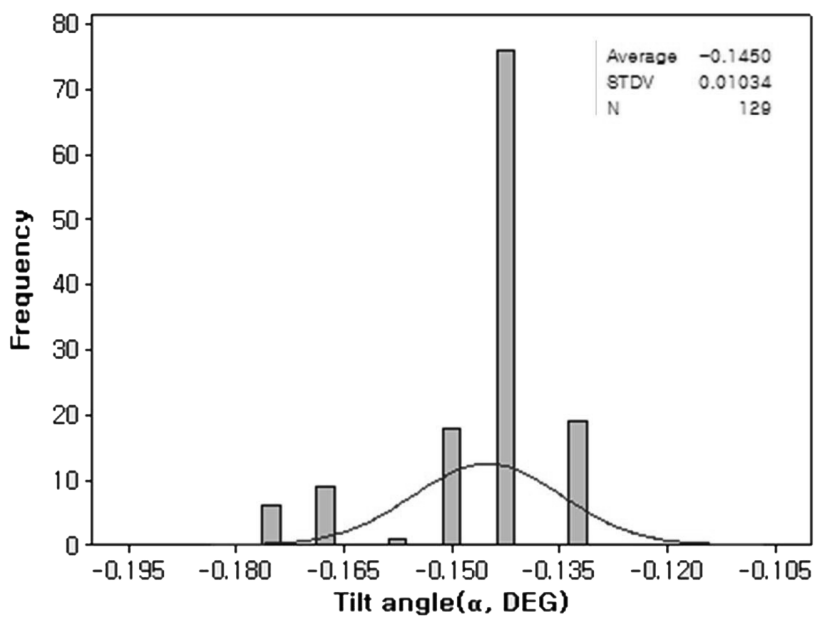

Fig. 4. Distribution of tilt angles of 129 sliced wafers (target $\alpha=-0.15$ ) 


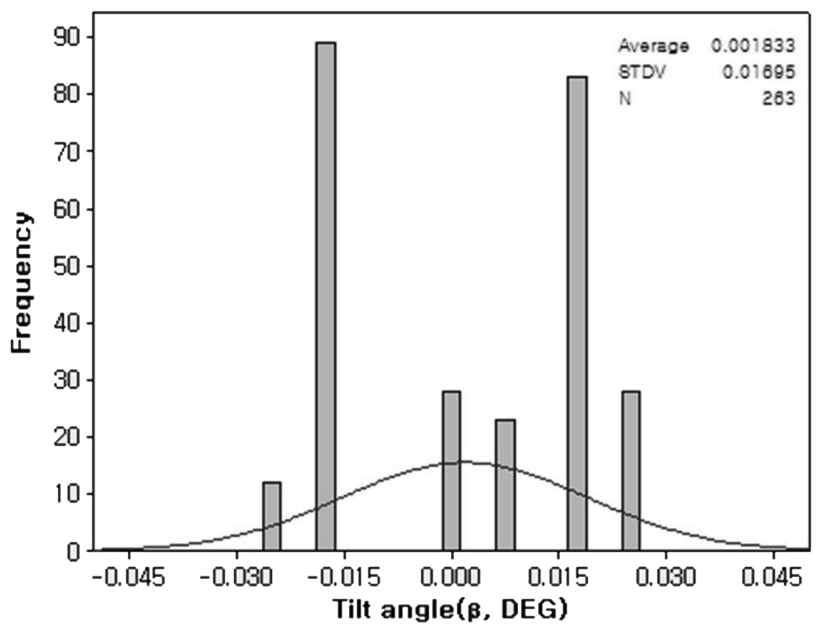

Fig. 5. Distribution of tilt angles of 263 sliced wafers (target $\beta=-0.1)$.

모두 가공오차 안에 들며, 통계적인 예측을 통해 현재의 표본에 대해서 $\pm 0.03^{\circ}$ 의 공차조건에서 장기적으로 $1.9 \%$ 의 불량률이 예측되었다. Fig. 4 는 $\alpha=-0.15^{\circ}$ 의 목표값 을 갖는 절단 기판 129 매에 대해 실측된 경사각 의 분 포도이며 평균은 $-0.15^{\circ}$ 이고 표준편차는 $0.0103^{\circ}$ 이며, $\pm 0.03^{\circ}$ 의 공차조건에서 장기적인 전체 불량률(기대전체 성능)은 $0.8 \%$ 로 예측된다. Fig. 5 는 경사각 $\beta=0.0^{\circ}$ 의 목표값을 갖는 Fig. 3, 4의 절단기판 263매에 대해서 실 측된 경사각 의 분포도이며 평균은 $-0.002^{\circ}$ 이고 표준편 차는 $0.0170^{\circ}$ 이며 $\pm 0.03^{\circ}$ 의 공차조건에서 장기적인 전 체 불량률(기대전체성능)은 $7.9 \%$ 로 예측된다. 따라서 $\mathrm{R}$-면 기판의 경사각을 $\pm 0.03^{\circ}$ 의 공차로 제어 가능함을 확인할 수 있었다.

\section{2. $\mathrm{R}$-면 기판의 평탄도}

Nidek사의 표면형상분석 장치를 이용하여 관찰된 R면 기판의 전형적인 표면 형상을 Fig. 6에 나타내었다. 경사각의 절대값이 $0 \sim 0.6^{\circ}$ 로 작은 범위를 가지기 때문에 경사각에 따른 표면형상과 평탄도의 차이는 거의 나타나 지 않았다. R-면 기판과 c-면 기판의 $\mathrm{BOW}, \mathrm{SORI}$ 값을 각각 1829 매와 2485 매의 기판에 대해서 측정한 결과를 Fig. 7에 나타내었다. R-면 기판의 BOW 값은 -12.30 $12.41 \mu \mathrm{m}$ 의 범위를 가지며, 평균 $\mathrm{BOW}$ 값은 $-2.22 \mu \mathrm{m}$ 를 나타내었다. 동일 가공조건을 갖는 $\mathrm{c}-$ 면 기판의 $\mathrm{BOW}$ 값은 $-10.99 \sim 8.10 \mu \mathrm{m}$ 의 범위를 가지며 평균 $\mathrm{BOW}$ 값은 -2.76 $\mu \mathrm{m}$ 를 나타냈다. 평균 $\mathrm{BOW}$ 값의 차이는 크지 않으나 상대적으로 R-면 기판의 $\mathrm{BOW}$ 값의 분포범위가 넓으며 이는 R-면 기판이 갖는 큰 이방성과 이에 따른 큰 절단 $\mathrm{BOW}$ 에 기인하는 것으로 판단된다. 한편 Fig. 7에서 $\mathrm{SORI}$ 를 비교하면, $\mathrm{R}$-면 기판의 SORI data는 1.34
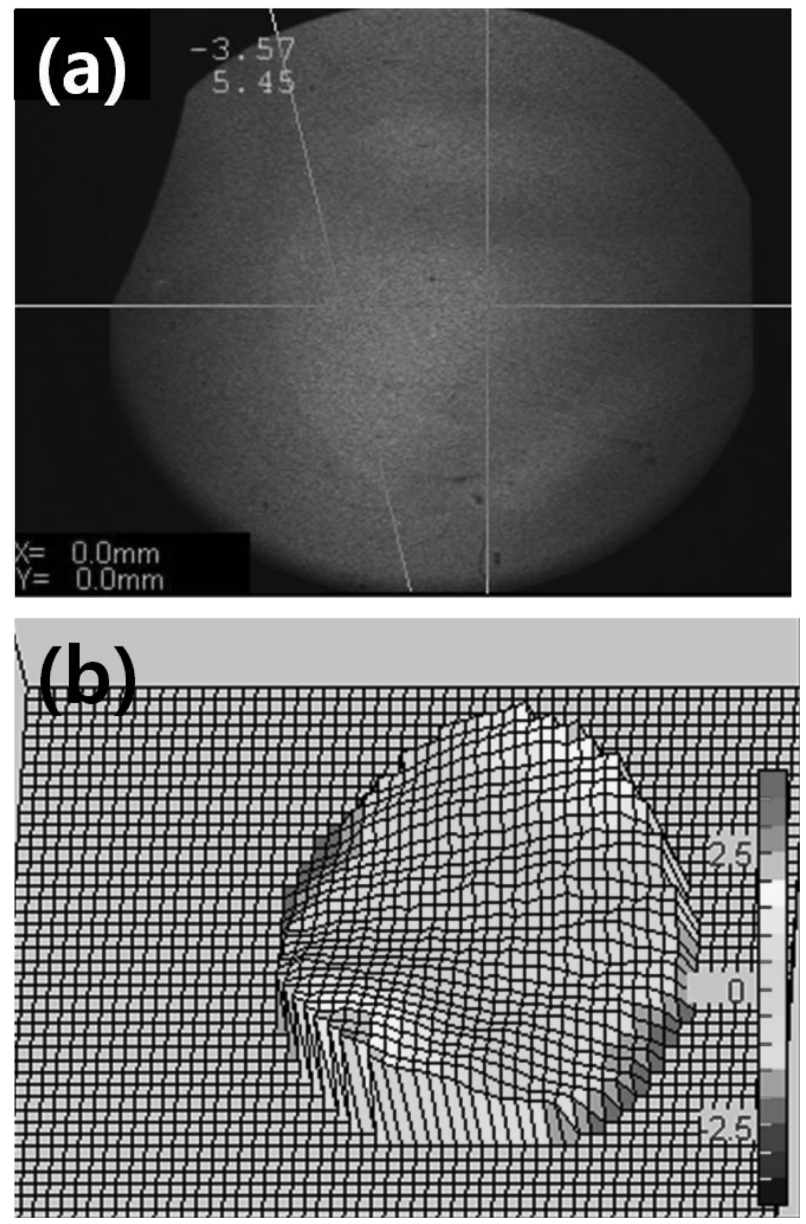

Fig. 6. Typical surface image of R-plane sapphire wafer (Nidek FT-17) (a) Fringe (b) Bird eye's view.

$20.29 \mu \mathrm{m}$ 를 나타내었고, 평균 SORI 값은 $7.23 \mu \mathrm{m}$ 를 나 타내었으며 c-면 기판의 SORI 값은 $0.89 ~ 11.23 \mu \mathrm{m}$ 를 나타내었고, 평균 SORI 값은 $3.36 \mu \mathrm{m}$ 를 나타내었다.

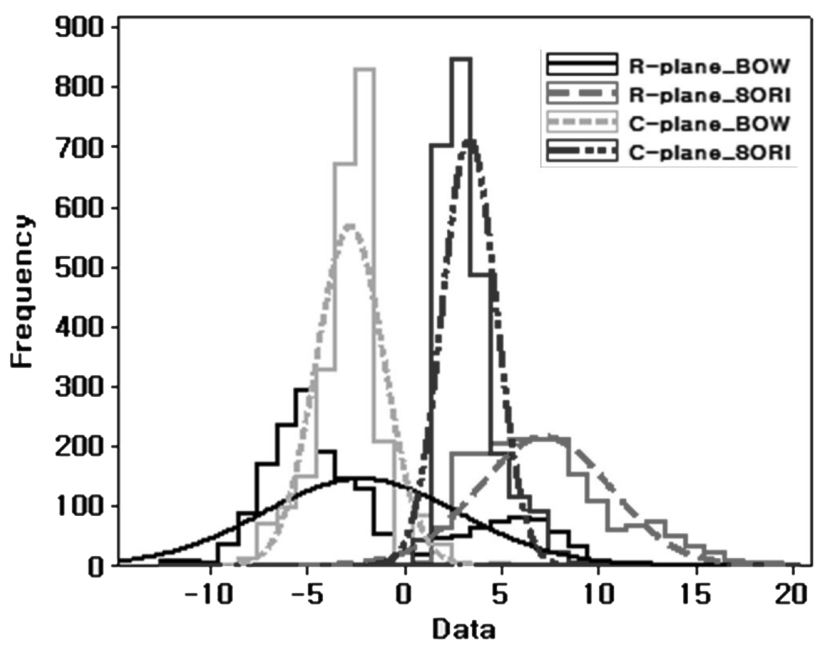

Fig. 7. Distribution of BOW and SORI data of R-plane and c-plane sapphire wafers. 


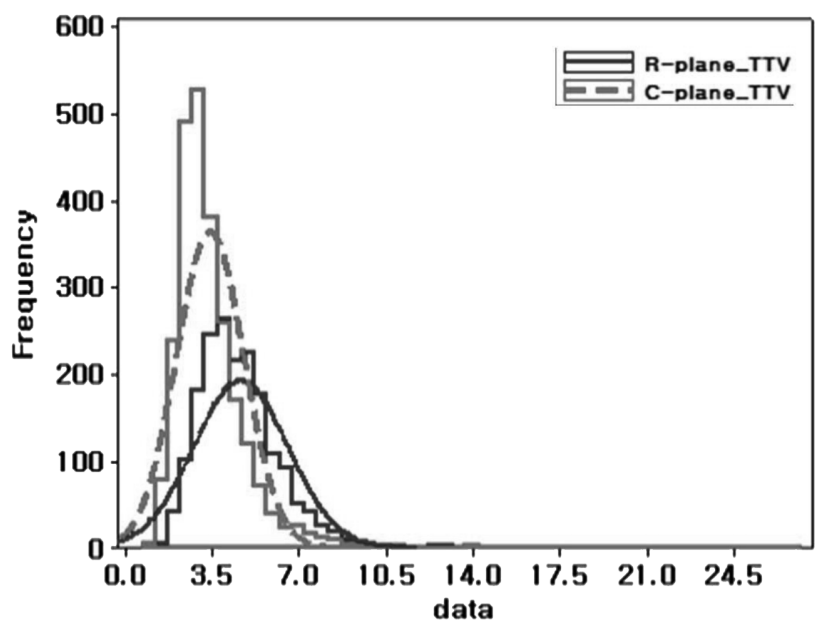

Fig. 8. Distribution of TTV data of R-plane and c-plane sapphire wafers.

BOW 값은 웨이퍼의 가운데 부분이 볼록하거나 오목 한 정도를 나타내는 값으로서 두 종류 기판의 평균 $\mathrm{BOW}$ 값은 유사한 (-) 값을 가지며 이는 기판의 전체적 인 형상이 약간 오목한 경향을 가짐을 알 수 있다. 그러 나 SORI 값은 오목 볼록에 관계없이 웨이퍼의 굴곡진 정도를 나타내는 값으로서 거의 양의 값으로 표시되며 값이 클수록 굴곡 정도가 크므로 R-면 웨이퍼가 c-면 웨 이퍼에 비해 굴곡이 심함을 알 수 있다. 이러한 굴곡 현 상은 Nidek 측정 형상을 확인한 결과 절단 시 발생한 절단 $\mathrm{BOW}$ 의 영향에 의한 것으로 판단된다.

$\mathrm{R}$-면과 c-면 기판을 각각 1830 매와 2485 매에 대해서 TTV를 측정한 결과를 Fig. 8에 나타내었다. R-면 기판 의 경우 $1.42 ~ 27.07 \mu \mathrm{m}$ 범위의 값을 나타내며 평균 TTV값은 $4.70 \mu \mathrm{m}$ 를 나타내었고, 유사한 공정조건에서 가공된 c-면 기판의 TTV data는 $0.98 ~ 15.01 \mu \mathrm{m}$ 범위의 값과 평균 $3.45 \mu \mathrm{m}$ 의 $\mathrm{TTV}$ 값을 나타내었다.

두께편차 측정 결과로는 $\mathrm{R}$-면 기판들의 평균 $\mathrm{TTV}$ 는 $4.70 \mu \mathrm{m}, \mathrm{c}$-면 기판의 경우에는 $3.45 \mu \mathrm{m}$ 의 결과를 나타 내어 R-면 웨이퍼가 c-면 에 비해 평탄도가 떨어지는 결 과를 나타내고 있으나, 이 정도의 TTV 값은 기존 사용 되고 있는 c-면 기판의 양산 기준 내에 포함되는 수준으 로 판단된다.

\section{3. 경면 거칠기}

Fig. 9는 경사각에 따른 R-면 기판의 $\mathrm{AFM}$ 관찰결과 이다. R-면 기판은 step 구조를 가지며 경사각에 따라 step 구조의 변화가 관찰되었으며, Fig. 10 의 $\mathrm{AFM}$ 영상 으로부터 측정된 step 구조의 변화는 경사각 $\alpha$ 가 $-0.12^{\circ}$ 에서 $-0.65^{\circ}$ 로 (-)방향으로 증가함에 따라 step의 너비 는 $156 \mathrm{~nm}$ 에서 $26 \mathrm{~nm}$, step의 높이는 $0.44 \mathrm{~nm}$ 에서 0.21
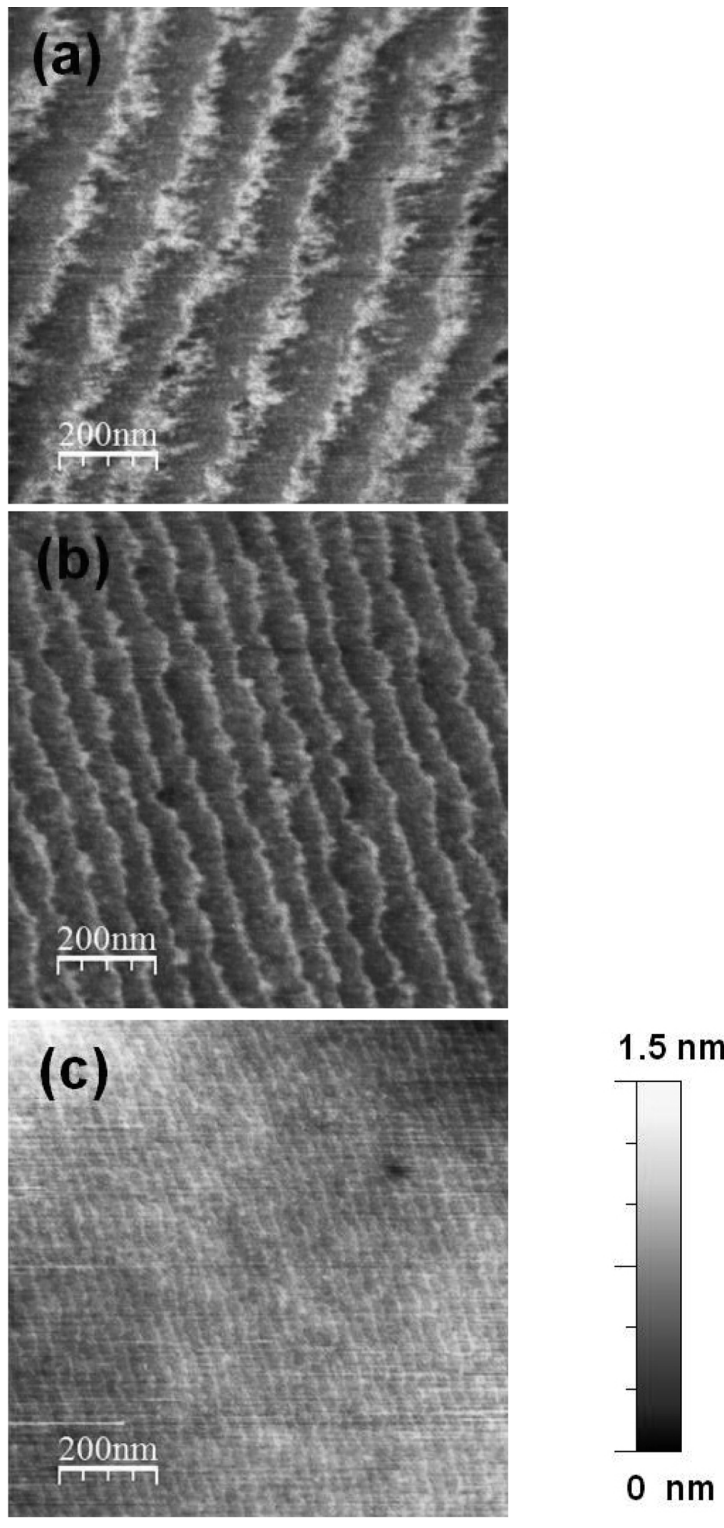

Fig. 9. AFM surface morphology of R-plane sapphire with tilt angle at (a) $\alpha=-0.1^{\circ}$ (b) $\alpha=-0.3^{\circ}$ (c) $\alpha=-0.6^{\circ}$.

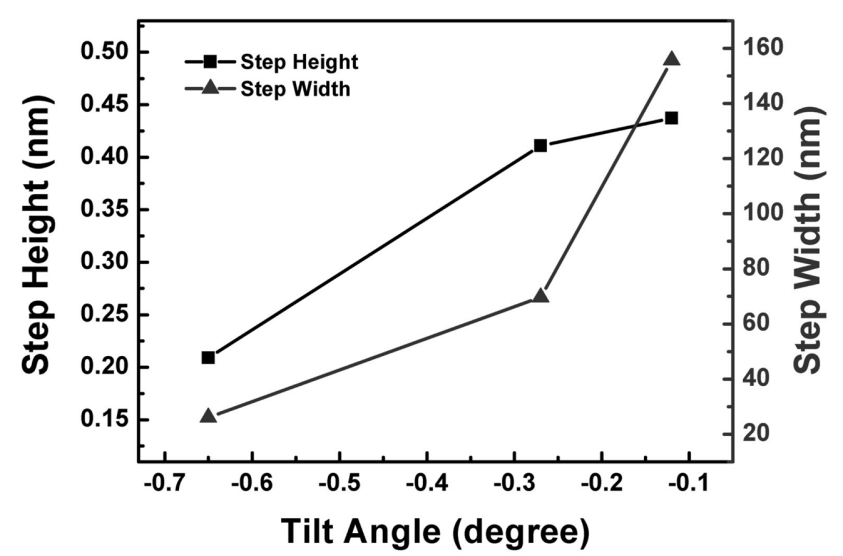

Fig. 10. Atomic step width and height of tilted R-plane sapphire substrate. 
$\mathrm{nm}$ 로 변화하였다. 경사각이 증가함에 따라 기판의 수직 방향은 c-축과 가까워지며 step 사이의 거리가 가까워진 다. 그러나 step의 높이는 $0.2 \sim 0.4 \mathrm{~nm}$ 범위에서 거의 일 정한 값을 갖는다. 이는 경사각이 증가함에 따라 $\mathrm{R}$-면의 면적은 거의 변화가 없는 반면에 c-면의 면적은 증가함 을 의미하며, 이와 같은 경사각의 변화에 따른 R-면 기 판의 step 구조의 변화는 epi 층의 성장거동 및 품질에 큰 영향을 미치며 양질의 비극성 $\mathrm{a}-\mathrm{GaN}$ 성장을 위해서 는 경사각의 정밀한 조절이 요구됨을 확인할 수 있었다 [13].

\section{4. 결 론}

비극성 사파이어 $\mathrm{R}$-면 기판의 경사각을 $\alpha=0,-0.1$, $-0.15,-0.2,-0.4,-0.6^{\circ}, \beta=0$ 을 목표값으로 가공하여 절단기판에 대한 경사각의 분포와 연마가공이 완료된 기 판의 기판특성에 대한 측정평가한 결과는 다음과 같다.

1) 절단공정의 제어를 통해서 $\mathrm{R}$-면 기판의 경사각 $\alpha$ 와 $\beta$ 를 $\pm 0.03^{\circ}$ 의 공차로 제어가능하였다.

2) 가공된 R-면 기판의 경사각의 절대값이 $0 \sim 0.6^{\circ}$ 로 작아 경사각에 따른 $\mathrm{BOW}, \mathrm{SORI}$, TTV 값이 변화는 나 타나지 않았으며, R-면 기판의 큰 이방성에 의해서 c-면 기판과 비교 시 넓은 분포를 나타내었다.

3) 경사각 변화에 의해 R-면 기판의 step 구조의 형상 변화가 나타나며, $\alpha$ 가 증가함에 따라 step 높이는 0.2 $0.4 \mathrm{~nm}$ 로 거의 변화가 없으나, step의 너비는 $156 \mathrm{~nm}$ 에 서 $26 \mathrm{~nm}$ 로 크게 감소하여 $\mathrm{R}$-면의 면적은 큰 변화가 없 는 반면 c-면의 면적이 증가하게 되며, $\mathrm{GaN}$ 에피 성장 에 영향을 주는 것으로 판단된다.

\section{참 고 문 헌}

[1] D. Miller, T.C. Damen, A.C. Gossard, W. Wiegmann, T.H. Wood and C.A. Burrus, "Electric field dependence of optical absorption near the band gap of quantum-well structures", Phys. Rev. Lett. 32(2) (1985) 1043.

[2 ] P. Waltereit, O. Brandt, A. Trampert, H.Y. Grahn, J. Menniger, M. Ramsteiner, M. Reiche and K.H. Ploog,
"Nitride semiconductors free of electrostatic fields for efficient white light-emitting diodes", Nature 406(24) (2000) 865.

[ 3 ] M.D. Craven, S.H. Lim, F. Wu, J.S. Speck and S.P. DenBaars, "Structural characterization of nonpolar (1120) a-plane $\mathrm{GaN}$ thin films grown on (1-102) r-plane sapphire", Appl. Phys. Lett. 81(3) (2002) 469.

[4] B.A. Haskell and F. Wu, "Structural and morphological characteristics of planar (11-20) a-plane gallium nitride grown by hydride vapor phase epitaxy", Appl. Phys. Lett. 83(8) (2003) 1554.

[5] M.D. Craven, P. Waltereit, J.S. Speck and S.P. DenBaars, "Microstructural evolution of a-plane GaN grown on a-plane $\mathrm{SiC}$ by metalorganic chemical vapor deposition", Appl. Phys. Lett. 84(8) (2004) 1281.

[6] Masataka Imura, Akira Hoshino, Kiyotaka Nakano, Michinobu Tsuda, Motoaki Iwaya, Satoshi Kamiyama, Hiroshi Amano and Isamu Akasaki, "Flat (11-20) GaN thin film on precisely offset-controlled (1-102) sapphire substrate", Jpn. J. Appl. Phys. 44(10) (2005) 7418.

[7] X. Ni, Y. Fu, Y.T. Moon, N. Biyikli and H. Morkoc, "Optimization of (11-20) a-plane GaN growth by MOCVD on (1-10-2) r-plane sapphire", J. Cryst. Growth 290 (2006) 166.

[ 8 ] Masahiro Araki, Noriaki Mochimizo, Katsuyuki Hoshino and Kazuyuki Tadatomo, "Effect of misorientation angle of r-plane sapphire substrate on a-plane $\mathrm{GaN}$ grown by metalorganic vapor phase epitaxy", Jpn. J. Appl. Phys. 47(1) (2008) 119.

[9] S.-M. Hwang, Y.G. Seo, K.H. Baik, I.-S. Cho, J.H. Baek, S. Jung, T.G. Kim and M. Cho, "Demonstration of nonpolar a-plane InGaN/GaN light emitting diode on r-plane sapphire substrate", Appl. Phys. Lett. 95 (2009) 071101.

[10] B.A. Haskell, S. Nakamura, S.P. DenBaars and J.S. Speck, "Progress in the growth of nonpolar gallium nitride", Phys. Stat. Sol.(b) 244(8) (2007) 2847.

[11] Honglin Zhu, Luiz A. Tessaroto, Robert Sabia, Victor A. Greenhut, Maynard Smith and Dale E. Niesz, "Chemical mechanical polishing(CMP) anisotropy in sapphire", Applied Surface Science 236 (2004) 120.

[12] J.K. Kang, J.H. Kim and Y.J. Kim, "Fabrication of Rplane sapphire wafer for nonpolar a-plane GaN", Journal of the Microelectronics \& Packaging Society 18(3) (2011) in press.

[13] S.H. Park, J. Park, D.-J. You, D. Moon, N. Kim, J. Kim, J. Kang, S.-M. Lee, J.-S. Kim, M.-S. Yang, T. Kim and E. Yoon, "Effects of r-plane sapphire substrate tilt angles on the growth behavior of non-polar a-plane GaN", will be published. 